\title{
Y掺杂的ZnO纳米纤维材料的制备及其气敏传感器作用机理
}

\author{
冯秋霞 ${ }^{1,2}$ 于 鹏1 王 貺1,* 李晓干1,* \\ ('大连理工大学电子科学与技术学院, 辽宁大连 116023; '大连东软信息学院电子工程系, 辽宁大连 116023)
}

\begin{abstract}
摘要: 采用静电纺丝法成功制备了Y掺杂的ZnO纳米纤维. 并通过X射线衍射(XRD), 扫描电子显微镜(SEM), 能量色散X射线(EDX), 透射电子显微镜(TEM)以及热重差热分析(TG-DTA)等手段对样品的结构和形貌进行了 表征分析. 同时用纯的 $\mathrm{nnO}$ 和Y掺杂的ZnO纳米纤维制备了传感器, 对浓度为 $(1-200) \times 10^{-6}$ (体积分数)丙酮的 气敏特性进行了测试分析. 测试结果表明, 可以通过简单控制纳米纤维中Y的含量, 来微调该传感器的气敏特 性. 同时也发现通过Y掺杂, ZnO纳米纤维对丙酮的气敏特性有所改善, 表现出很高的响应. 纯 ZnO和Y掺杂 $\mathrm{ZnO}$ 制成的传感器对几种潜在干扰气体表现出良好的选择性, 比如氨气、苯、甲醛、甲苯以及甲醇. 本文最后 也讨论了该传感器的气敏作用机理.
\end{abstract}

关键词: 气体传感器; $\mathrm{ZnO}$ 纳米纤维; Y掺杂; 静电纺丝; 丙酮 中图分类号: 0641; O642; 0649

\section{Preparation of Y-Doped ZnO Nanofibers and Sensing Mechanism of the Gas Sensors}

\author{
FENG Qiu-Xia ${ }^{1,2} \quad$ YU Peng ${ }^{1} \quad$ WANG Jing ${ }^{1, *} \quad$ LI Xiao-Gan ${ }^{1, *}$ \\ ('School of Electronic Science and Technology, Dalian University of Technology, Dalian 116023, Liaoning Province, P. R. China; \\ ${ }^{2}$ Department of Electronic Engineering, Dalian Neusoft University of Information, Dalian 116023, Liaoning Province, P. R. China)
}

\begin{abstract}
Y-doped $\mathrm{ZnO}$ nanofibers were synthesized by an electrospinning method. The structure and morphology of the samples were characterized using X-ray diffraction (XRD), scanning electron microscopy (SEM), energy dispersive X-ray (EDX), transmission electron microscopy (TEM), and thermogravimetric/differential thermal analysis (TG-DTA). The sensitivity of the pure and Y-doped $\mathrm{ZnO}$ nanofibers towards acetone from $1 \times 10^{-6}$ to $200 \times 10^{-6}$ (volume fraction) was investigated. Fine tuning of the sensing ability of the $\mathrm{ZnO}$ nanofibres was possible by controlling the amount of $\mathrm{Y}$ loaded in the nanofibers. The $\mathrm{ZnO}$ nanofibers doped with $\mathrm{Y}$ exhibited very high responses towards acetone. Both the pure and $\mathrm{Y}$-doped $\mathrm{ZnO}$ sensors showed selectivity towards several potential interferent gases, including ammonia, benzene, formaldehyde, toluene, and methanol. The sensing mechanism is discussed.
\end{abstract}

Key Words: Gas sensor; ZnO nanofiber; Y dopant; Electrospinning; Acetone

\section{Introduction}

As an important II-VI semiconducting material with a wide direct band gap $\left(E_{\mathrm{g}}=3.37 \mathrm{eV}\right.$ at $\left.300 \mathrm{~K}\right)$ and a large exciton binding energy ( $\sim 60 \mathrm{meV}), \mathrm{ZnO}$ has drawn much attention in the last few decades owing to its specific electrical, catalytic, and photochemical optoelectronic properties. ${ }^{1,2}$ Recently, $\mathrm{ZnO}$ has been widely studied in gas sensing application due to its good response to a variety of reducing or oxidizing gases such as $\mathrm{CO}, \mathrm{H}_{2}, \mathrm{NH}_{3}, \mathrm{C}_{2} \mathrm{H}_{5} \mathrm{OH}$, and $\mathrm{CH}_{3} \mathrm{COCH}_{3}$. However, it was found that sensors based on $\mathrm{ZnO}$ showed some disadvantages

Received: September 9, 2015; Revised: October 23, 2015; Published on Web: October 26, 2015.

"Corresponding authors. WANG Jing, Email: wangjing@dlut.edu.cn. LI Xiao-Gan, Email: 1ixg@dlut.edu.cn; Tel: +86-411-84706710.

The project was supported by the National Natural Science Foundation of China $(61474012,61176068,61574025,61131004)$.

国家自然科学基金(61474012, 61176068, 61574025, 61131004)资助项目

(C) Editorial office of Acta Physico-Chimica Sinica 
such as low sensitivity, high working temperature, and restricted detection of gases in low concentrations..$^{3-5}$

One way to enhance gas sensing properties is doping impurity elements..$^{6-8}$ For example, Niu et al. ${ }^{9}$ used $\mathrm{Fe}, \mathrm{Co}$, and $\mathrm{Cr}$ as dopants to improve the gas sensing property of pure $\mathrm{ZnO}$, and the as-prepared $\mathrm{ZnFe}_{2} \mathrm{O}_{4}$ showed high sensitivity and good selectivity to $\mathrm{Cl}_{2}$. Sahay and $\mathrm{Nath}^{10}$ prepared Al-doped $\mathrm{ZnO}$ sensors for liquid petroleum gas (LPG), and the response increased by $1-2$ orders in magnitude at an operating temperature of $300{ }^{\circ} \mathrm{C}$. In addition, other metals such as $\mathrm{Y}, \mathrm{Pd}$ and etc were also used as dopants to improve gas sensing property of $\mathrm{ZnO}$. The electrical, chemical and gas sensing properties of $\mathrm{ZnO}$ were significantly affected by doped Y element. ${ }^{11-14}$ Kılınç et al. ${ }^{15}$ prepared $\mathrm{Y}$-doped $\mathrm{ZnO}$ films by using sol-gel dip coating method which improved the sensing properties of $\mathrm{ZnO}$ and showed a high sensitivity to $\mathrm{NO}_{2}$. Besides, one-dimensional (1D) nanostructure material possesses high surface-to-volume ratio, which is an important factor for high sensing performance. ${ }^{16-18}$ Cheng et al. ${ }^{19}$ fabricated $\mathrm{Y}$-doped $\mathrm{SnO}_{2}$ hollow nanofibers based gas sensor which exhibited good stability and excellent selectivity attributed to the 1D hollow nanostructure and the effect of $Y$ doping.

In this work, pure and $\mathrm{Y}$-doped $\mathrm{ZnO}$ nanofibers were synthesized by using an electrospinning technology. The nanofibers show hierarchical structure. The corresponding chemoresistive gas sensors displayed an excellent sensitivity to acetone with a fast response/recovery speed. The sensing mechanism of Y-doped $\mathrm{ZnO}$ nanofibers was briefly analyzed.

\section{Experimental}

\subsection{Preparation and characterization of pure and Y-doped ZnO nanofibers}

All the starting materials were analytical grade and were used without further purification. Zinc nitrate hexhydrate $\left(\mathrm{Zn}\left(\mathrm{NO}_{3}\right)_{2} \cdot 6 \mathrm{H}_{2} \mathrm{O}\right)$ and yttrium nitrate hexhydrate $\left(\mathrm{Y}\left(\mathrm{NO}_{3}\right)_{3} \cdot\right.$ $6 \mathrm{H}_{2} \mathrm{O}$ ) were purchased from Tianjin Kermel Chemical Corporation, China. Polyvinyl pyrrolidone (PVP, $M_{\mathrm{w}}=1300000$ $\mathrm{g} \cdot \mathrm{mol}^{-1}$ ) was purchased from Sigma-Aldrich, USA. $N, N$-dimethylformamide (DMF) and absolute ethanol (EtOH) were purchased from Sinopharm Chemical Reagent Co. Ltd., China. $\mathrm{Zn}\left(\mathrm{NO}_{3}\right)_{2} \cdot 6 \mathrm{H}_{2} \mathrm{O}$ and $\mathrm{Y}\left(\mathrm{NO}_{3}\right)_{3} \cdot 6 \mathrm{H}_{2} \mathrm{O}$ were used as $\mathrm{Zn}$ and $\mathrm{Y}$ sources, respectively. $\mathrm{Y}$-doped $\mathrm{ZnO}$ nanofibers with different doping concentrations of $\mathrm{Y}$ were prepared by electrospinning method. In a typical procedure, the same amount of $\mathrm{Zn}\left(\mathrm{NO}_{3}\right)_{2} \cdot 6 \mathrm{H}_{2} \mathrm{O}(1 \mathrm{~g})$ and a certain amount of $\mathrm{Y}\left(\mathrm{NO}_{3}\right)_{3} \cdot 6 \mathrm{H}_{2} \mathrm{O}$ were dissolved in $9 \mathrm{~mL}$ ( $4 \mathrm{~mL}$ DMF and $5 \mathrm{~mL}$ ethanol) cosolvent with magnetically stirring for $1 \mathrm{~h}$. Subsequently, $1 \mathrm{~g}$ PVP was added into the above solution with another magnetically stirring for $12 \mathrm{~h}$. The as-prepared mixture was aged at room temperature for $1 \mathrm{~h}$, and then used as the precursor for the following electrospinning process.

The precursor solution was loaded into a plastic syringe equipped with an N7-gauge needle made of stainless steel. A voltage of $18 \mathrm{kV}$ was applied between the needle (positive) and the collecting foil (negative). The distance between the needle tip and the collecting foil was $13.5 \mathrm{~cm}$. A syringe pump was used to apply a force to ensure a feeding rate for the precursor solution at $0.3 \mathrm{~mL} \cdot \mathrm{h}^{-1}$. After the electrospinning procedure, the as-spun nanofibers were calcined at $500{ }^{\circ} \mathrm{C}$ in air for $3 \mathrm{~h}$. A slow heating rate $\left(2{ }^{\circ} \mathrm{C} \cdot \mathrm{min}^{-1}\right)$ was selected to ensure the removal of organic phase without destroying the nanofibrillar structure and to avoid disintegration of the oxide nanofibers. ${ }^{16-18}$ A serials of $\mathrm{Y}$-doped $\mathrm{ZnO}$ samples were prepared ( $\mathrm{Y}$ content: $1 \%, 3 \%$, and $6 \%$ (atomic fraction), respectively), and pure $\mathrm{ZnO}$ was prepared by the above method but without $\mathrm{Y}\left(\mathrm{NO}_{3}\right)_{3} \cdot 6 \mathrm{H}_{2} \mathrm{O}$.

The thermal gravimetric and differential thermal analysis (TG-DTA) of the precursor was analyzed by using a TA $910 \mathrm{~S}$ (United States) and NETZSCH TGA-209C (Germany) from 20 to $700{ }^{\circ} \mathrm{C}$ at a heating rate of $10{ }^{\circ} \mathrm{C} \cdot \mathrm{min}^{-1}$ in air. The X-ray diffraction patterns (XRD) of the samples were characterized by a Shimadzu XRD-6000 (Japan) in $2 \theta$ region of $20^{\circ}-80^{\circ}$ with $\mathrm{Cu}$ $K_{a, 1}(0.15406 \mathrm{~nm})$ radiation. The morphologies were analyzed on a FEI QUANTA 200F (USA) microscope equipped (FESEM) with energy-dispersive X-ray (EDX) spectroscopy. The TEM images were recorded with a Tecnai G220 S-Twin instrument (Philips, The Netherlands).

\subsection{Fabrication and measurement of gas sensors}

About $2 \mathrm{mg}$ of the as-prepared $\mathrm{Y}$-doped $\mathrm{ZnO}$ nanofibers were mixed with a suitable amount of deionized water $(100 \mu \mathrm{L})$ to form a paste. Then the paste was coated on commercial alumina tube (outer diameter: $1.2 \mathrm{~mm}$ ) (Siping Jihua Advanced Technology CO., Ltd., Siping, China), on which a pair of Au electrodes (with a gap of $0.8 \mathrm{~mm}$ ) and two Pt wires had been previously printed and installed at each end. After the alumina tube was calcined at $300{ }^{\circ} \mathrm{C}$ for $2 \mathrm{~h}$, a Ni-Cr heating wire was inserted into the tube to form an inside-heated gas sensor. ${ }^{20}$ The alumina tube was then welded onto a pedestal with six pins to give the final sensor unit. Before the measurement, the sensors were pre-heated at different operating temperatures for about 30 min and aged at $300{ }^{\circ} \mathrm{C}$ for several days to enhance the stabilization. The gas sensing tests were operated in a static state gassensing test system. ${ }^{21}$ When the resistances of all the sensors were stable, target gas was injected into the test chamber by a micro-injector through a rubber plug. To obtain the recovery of the sensor response, the front window of the chamber was opened and the gas vapors released out spontaneously. The response value $(S)$ was defined as $S=R_{\mathrm{a}} / R_{\mathrm{g}}$, where $R_{\mathrm{a}}$ was the sensor resistance in air (base resistance) and $R_{\mathrm{g}}$ was the resistance of the sensor in target gas. The time taken by the sensor to achieve $90 \%$ of the total resistance change was defined as the response time in the case of response (target gas adsorption), or the recovery time in the case of recovery (target gas desorption). The whole system was controlled by a computer automatically. The relative humidity in the chamber was $40 \%$.

\section{Results and discussion}

\subsection{Characterization properties of sensing materials}

The TG-DTA curves of PVP/Zn( $\left(\mathrm{NO}_{3}\right) \cdot 6 \mathrm{H}_{2} \mathrm{O} / \mathrm{Y}\left(\mathrm{NO}_{3}\right)_{3} \cdot 6 \mathrm{H}_{2} \mathrm{O}$ 
composite nanofibers are shown in Fig.1. The weight losses $(\sim 77.14 \%)$ found from TGA curves agree fairly well with those expected to the decomposition of PVP and $\mathrm{Zn}\left(\mathrm{NO}_{3}\right)_{2} \cdot 6 \mathrm{H}_{2} \mathrm{O}$ / $\mathrm{Y}\left(\mathrm{NO}_{3}\right)_{3} \cdot 6 \mathrm{H}_{2} \mathrm{O}$ and the formation of oxide. The TGA curve of $\mathrm{PVP} / \mathrm{Zn}\left(\mathrm{NO}_{3}\right) \cdot 6 \mathrm{H}_{2} \mathrm{O} / \mathrm{Y}\left(\mathrm{NO}_{3}\right)_{3} \cdot 6 \mathrm{H}_{2} \mathrm{O}$ blend seems to indicate three stages of decomposition. The first one is attributed to the liberation of a small amount of moisture. The second weight loss occurs at around $220-320{ }^{\circ} \mathrm{C}$ due to loss of water of crystallization and melting temperature of the polymer $\left(T_{\mathrm{m}}=110-\right.$ $180^{\circ} \mathrm{C}$ ) that the shift of the melting temperature of PVP should be attributed to the presence of nitrate in the samples. ${ }^{22}$ The third stage is observed in a range of $350-480{ }^{\circ} \mathrm{C}$, which may correspond to the structural decomposition of organic phase. When the temperature reaches about $500{ }^{\circ} \mathrm{C}$, the curve becomes flat which indicates that the composite nanofibers have completely transformed into inorganic oxide nanofibers. $500{ }^{\circ} \mathrm{C}$ was chosen as the calcination temperature for crystallines prefection.

Fig.2(a) shows the XRD patterns of pure $\mathrm{ZnO}$ nanofibers of wurtzite hexagonal phase nanostructures with different calcination temperatures $\left(350,400,450,500,550,600\right.$, and $\left.650{ }^{\circ} \mathrm{C}\right)$, which are consistent with the values in the standard card (JCPDS card \# 89-1397). It is found that as the calcination temperature increases, the XRD diffraction peaks become higher and more narrow. All the diffraction peaks can be indexed as $\mathrm{ZnO}$ with lattice constants of $a=0.3259 \mathrm{~nm}$ and $c=0.5222 \mathrm{~nm}$ calculated by means of Rietveld refinement method. The average crystallite sizes of the pure $\mathrm{ZnO}$ nanofibers calcined at different temperatures were estimated from Scherrer equation, which were $25 \mathrm{~nm}\left(350^{\circ} \mathrm{C}\right), 32 \mathrm{~nm}\left(400{ }^{\circ} \mathrm{C}\right), 38 \mathrm{~nm}\left(450^{\circ} \mathrm{C}\right)$, $44 \mathrm{~nm}\left(500^{\circ} \mathrm{C}\right), 71 \mathrm{~nm}\left(550^{\circ} \mathrm{C}\right), 79 \mathrm{~nm}\left(600^{\circ} \mathrm{C}\right)$, and $81 \mathrm{~nm}$ $\left(650^{\circ} \mathrm{C}\right)$. It is indicated that the higher the calcination temperature, the larger the crystallite size and the better the crystallinity in this temperature range.

The crystal structures of different concentration of $\mathrm{Y}$-doped $\mathrm{ZnO}$ after $500{ }^{\circ} \mathrm{C}$ calcination were also characterized by XRD analysis as shown in Fig.2(b). All the diffraction patterns fit to a hexagonal phase $\mathrm{ZnO}$ crystal structure, and no peaks of $\mathrm{Y}_{2} \mathrm{O}_{3}$ are observed due to the small loading amount. ${ }^{23,24}$ Although no

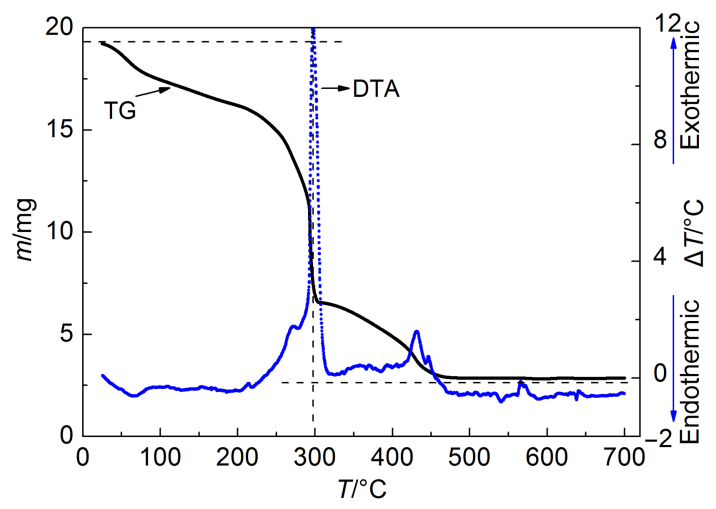

Fig.1 TG-DTA curves of $\mathrm{PVP} / \mathrm{Zn}\left(\mathrm{NO}_{3}\right) \cdot 6 \mathrm{H}_{2} \mathrm{O} / \mathrm{Y}\left(\mathrm{NO}_{3}\right)_{3} \cdot 6 \mathrm{H}_{2} \mathrm{O}$ composite nanofiber additional reflexes belong to $\mathrm{Y}_{2} \mathrm{O}_{3}$, the $\mathrm{Y}$-doped $\mathrm{ZnO}$ characteristic peak (101) initially shifts to higher angle $2 \theta$, and then an irregular change in the position of the peaks is observed for the samples doped with no less than $3 \%$ of $\mathrm{Y}$ in the insetted figure in Fig.2(b), which is consistent with the data reported in the literature. ${ }^{25}$ The average crystallite size and lattice parameters of the $\mathrm{Y}$-doped $\mathrm{ZnO}$ nanofibers calcined at $500{ }^{\circ} \mathrm{C}$ for $3 \mathrm{~h}$ are shown in Table 1. As can be seen, the crystallite size decreases with $\mathrm{Y}$ doping. The average crystallite sizes of the $\mathrm{ZnO}$ particles doped with $1 \%, 3 \%$, and $6 \%$ of $Y$ are calculated to be 37,33 , and $35 \mathrm{~nm}$, respectively, which is smaller than that of the pure $\mathrm{ZnO}$ nanoparticles (44 nm). These results reveal that $\mathrm{Y}$ inhibits the growth of $\mathrm{ZnO}$ nanoparticles. The lattice parameters of pure $\mathrm{ZnO}$ and $\mathrm{Y}$-doped $\mathrm{ZnO}$ were calculated by Rietveld refinement method, as shown in Table 1 . The $\mathrm{ZnO}$ lattice parameters $a$ and $c$ initially increase with $\mathrm{Y}$ doping for concentration $\leq 3 \%$. This may be ascribed to the lattice expansion caused by substitution of $0.074 \mathrm{~nm}$ sized $\mathrm{Zn}^{2+}$ ions with $0.093 \mathrm{~nm}$ sized $\mathrm{Y}^{3+}$ ions. When the concentration of $\mathrm{Y}$ is $6 \%$, the lattice parameters $a$ and $c$ decrease. The possible reason is that $\mathrm{Y}$ ions are
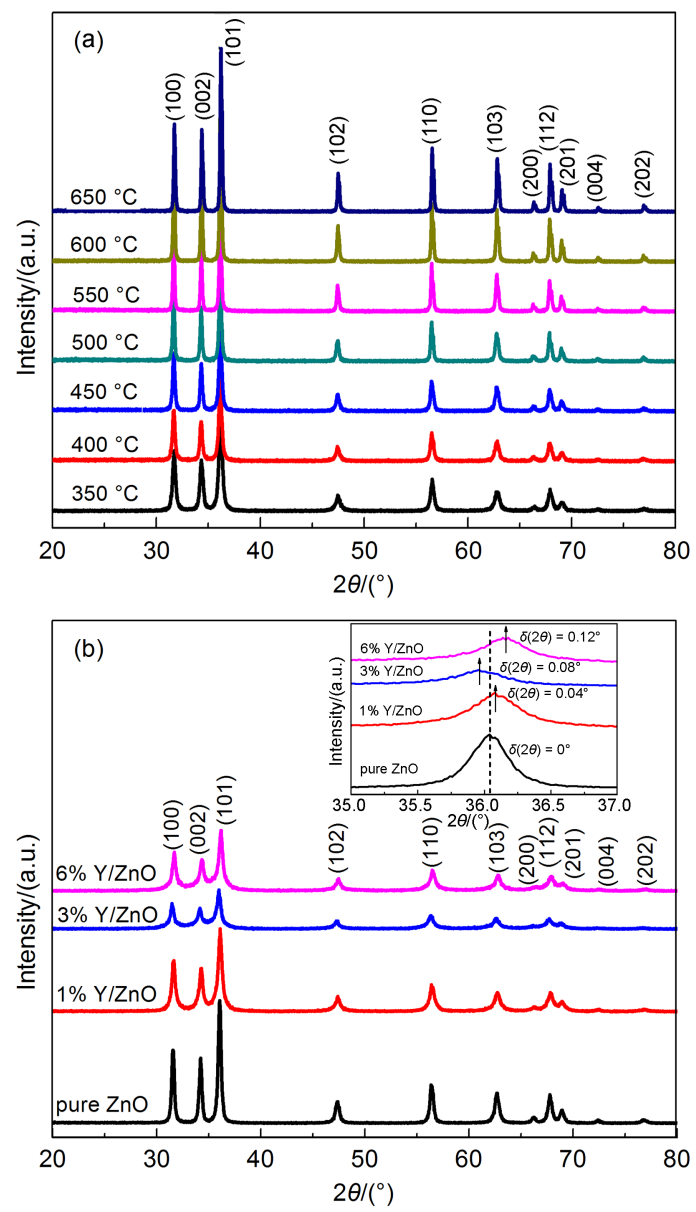

Fig.2 XRD patterns (a) pure $\mathrm{ZnO}$ nanofibers with different calcination temperatures, (b) $\mathrm{Y}$-doped $\mathrm{ZnO}$ nanofibers calcined at $500{ }^{\circ} \mathrm{C}$ for $3 \mathrm{~h}$

The insetted figure in (b) shows the changes in the (101) peak position with $\mathrm{Y}$ concentration. 
Table 1 Average crystallite size and lattice parameters of the Y-doped $\mathrm{ZnO}$ nanofibers calcined at $500{ }^{\circ} \mathrm{C}$ for $3 \mathrm{~h}$

\begin{tabular}{ccccc}
\hline Sample & Crystallite size $/ \mathrm{nm}$ & $a / \mathrm{nm}$ & $c / \mathrm{nm}$ & Volume $/ \mathrm{nm}^{3}$ \\
\hline pure $\mathrm{ZnO}$ & 44 & 0.3259 & 0.5222 & 0.04803 \\
$1 \% \mathrm{Y} / \mathrm{ZnO}$ & 37 & 0.3261 & 0.5223 & 0.04809 \\
$3 \% \mathrm{Y} / \mathrm{ZnO}$ & 33 & 0.3269 & 0.5236 & 0.04845 \\
$6 \% \mathrm{Y} / \mathrm{ZnO}$ & 35 & 0.3256 & 0.5212 & 0.04784 \\
\hline
\end{tabular}

incorporated in the interstitial sites.

The FE-SEM images of the as-prepared nanofibers of pure $\mathrm{ZnO}$ and $\mathrm{Y}$-doped $\mathrm{ZnO}$ calcined at $500{ }^{\circ} \mathrm{C}$ for $3 \mathrm{~h}$ are shown in Fig.3. As shown in Fig.3(a-d), the samples show mainly the nanofiber microstructure with the length up to several micrometers composed of small nanoparticles, which make the surface of the nanofibers considerably rough as shown in the insetted figure in Fig.3 $(\mathrm{a}-\mathrm{d})$. The diameter of the cross-section of the pure $\mathrm{ZnO}$ nanofibers is $500-600 \mathrm{~nm}$ which is composed of bigger nanoparticles than those of $1 \%, 3 \%$, and $6 \% \mathrm{Y}$-doped $\mathrm{ZnO}$ which have diameter of 200-300 nm. It seems that $\mathrm{Y}$ doping inhibits the formation of the bigger nanoparticles. This is consistent with the XRD pattern data. Fig.3(e, f) shows the EDX results of elemental chemical composition of pure $\mathrm{ZnO}$ and $1 \%$ Y-doped $\mathrm{ZnO}$, respectively. The EDX pattern clearly indicates that only three essential constituents such as $\mathrm{Zn}, \mathrm{O}$, and $\mathrm{Y}$ are detected from the observed spectrum, revealing the perfect doping and the absence of other impurities in the samples. The $\mathrm{Y}$ content is about $1.1 \%$ (the atomic ratio of $\mathrm{Zn}$ : $\mathrm{Y}$ is $98.9: 1.1)$. Pt is used to enhance the electrical conductivity of the materials during the observing process.

To unveil morphologies of the prepared samples of the pure and Y-doped $\mathrm{ZnO}$ nanofibers more clearly, we show low- and high-resolution TEM images in Fig.4(a-f). Fig.4(a) shows the
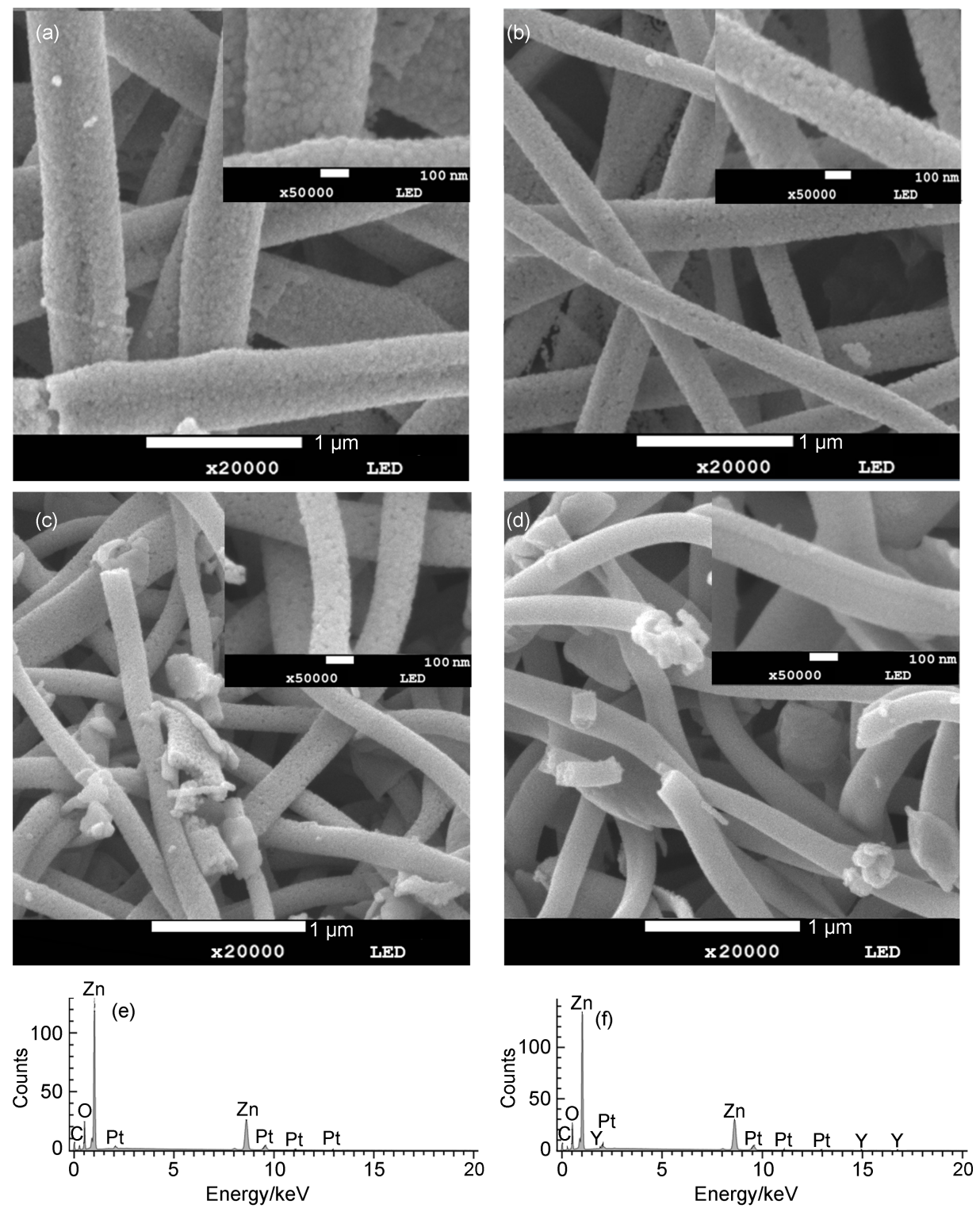

Fig.3 SEM images of Y-doped $\mathrm{ZnO}$ nanofibers calcined at $500{ }^{\circ} \mathrm{C}$ for $3 \mathrm{~h}$ of (a) pure $\mathrm{ZnO}$, (b) $1 \%$ Y-doped $\mathrm{ZnO}$, (c) $3 \%$ Y-doped $\mathrm{ZnO}$, and (d) $6 \%$ Y-doped ZnO; EDX spectra of (e) pure $\mathrm{ZnO}$ and (f) $1 \%$ Y-doped $\mathrm{ZnO}$ 

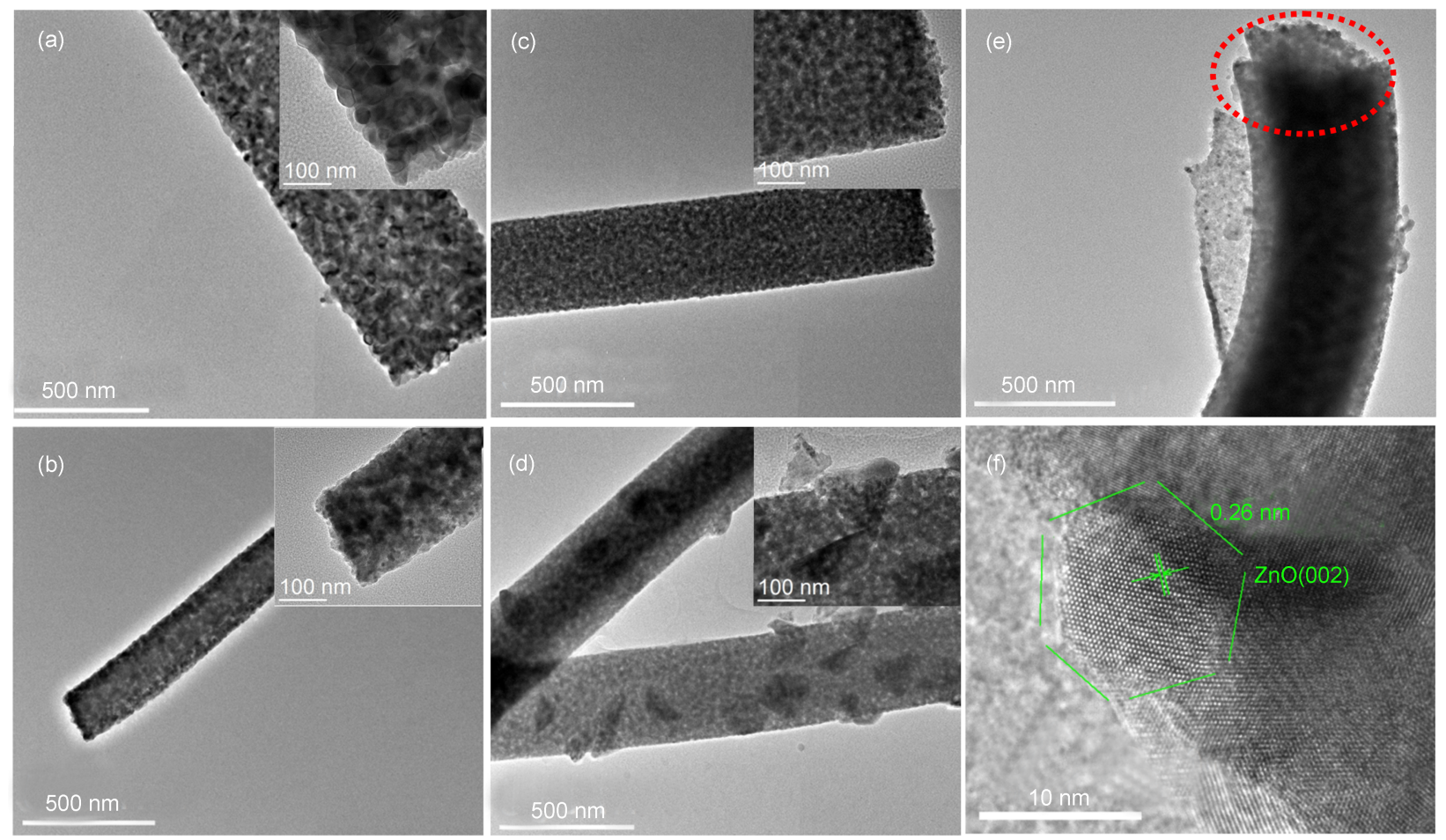

Fig.4 Low-magnification TEM images of (a, b) pure ZnO nanofibers, (c, d) $1 \%$ Y-doped ZnO nanofibers, (e) the hierarchical nanostructure of pure $\mathrm{ZnO}$ nanofibers, and (f) high-resolution TEM image of pure $\mathrm{ZnO}$ nanofibers calcined at $500{ }^{\circ} \mathrm{C}$ for $3 \mathrm{~h}$

pure $\mathrm{ZnO}$ nanofibers with bigger cross-section diameter and bigger particle size than those of $1 \%, 3 \%$, and $6 \%$ Y-doped $\mathrm{ZnO}$ nanofibers as shown in Fig.4(b-d), respectively. A hierarchical nanostructure was also found in the TEM images as shown in the circle of Fig.4(e). Obviously, such microstructure could increase the surface-to-volume ratio of the nanofibers to benifit of the gas diffusion and mass transport in the materials, and then improve the sensing properties of the material. Fig.4(f) presents a high-resolution TEM (HRTEM) image of an edge of a pure $\mathrm{ZnO}$ nanofiber, from which lattice fringes are clearly visible. The spacing between neighboring lattice planes is estimated to be $\sim 0.26 \mathrm{~nm}$ corresponding to the (002) planes of a hexagonal $\mathrm{ZnO} .{ }^{26}$ There were no lattice planes belonging to $\mathrm{Y}_{2} \mathrm{O}_{3}$ in the HRTEM image of $\mathrm{Y}$-doped $\mathrm{ZnO}$ nanofibers which was due to the small loading amount of $Y$.

\subsection{Gas sensing properties}

Acetone is a very important solvent applied in industries e.g., explosives, plastic, rubber, fiber, leather, grease, paint and etc. However, it is volatile and combustible. It is essential to detect acetone of low concentration. ${ }^{27}$ The electrospun Y-doped $\mathrm{ZnO}$ nanofibers based chemoresistive sensor shows very good sensitivity to acetone. Fig. 5 shows the responses of pure, 1\%, 3\%, and $6 \% \mathrm{Y}$-doped $\mathrm{ZnO}$ nanofibers to $100 \times 10^{-6}$ (volume fraction) acetone with the temperature varying from 330 to $500{ }^{\circ} \mathrm{C}$. At first, the response increases with the temperature. When the temperature rises to some value, the response reaches the maximum value. After that, the response begins to decrease. The corresponding temperature for the maximum response is called optimal operating temperature. The optimal operating temperature of pure, $1 \%, 3 \%$, and $6 \% \mathrm{Y}$-doped $\mathrm{ZnO}$ nanofibers based sensors is around $440{ }^{\circ} \mathrm{C}$. This behavior can be explained from the kinetics and mechanics of gas adsorption and desorption on the surface of $\mathrm{ZnO}$-like semiconducting metal oxides. When the operating temperature is low, the chemical activity of metal oxide is low, which leads to a very low response. On the other hand, when the temperature is too high, a part of adsorbed gas molecules may escape before they react with the sensing material due to their enhanced kinetic energy, which also leads to a decreased response. ${ }^{28-30}$ At the optimal temperature, $1 \% \mathrm{Y}$ doped $\mathrm{ZnO}$ nanofibers based sensor exhibits the highest response about 72 . The base resistances of the sensors based on pure, $1 \%, 3 \%$, and $6 \% \mathrm{Y}$-doped $\mathrm{ZnO}$ nanofibers were about 3 ,

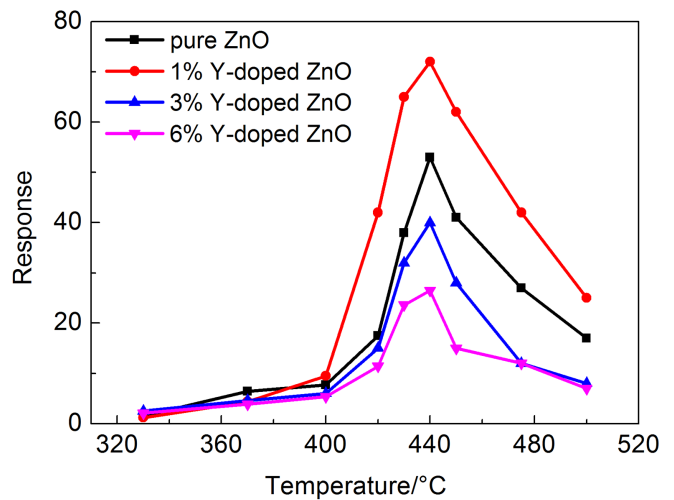

Fig.5 Responses of pure, $1 \%, 3 \%$, and $6 \%$ Y-doped $\mathrm{ZnO}$ nanofibers to $100 \times 10^{-6}$ acetone at different temperatures 
50,125 , and $600 \mathrm{M} \Omega$, respectively. This is because the increase of oxygen vacancies and other defects introduced by $\mathrm{Y}$ doping will reduce the mobility of free electrons. ${ }^{31,32}$

The responses of $1 \% \mathrm{Y}$-doped $\mathrm{ZnO}$ nanofibers to acetone of different concentrations $\left((1-200) \times 10^{-6}\right)$ at $440^{\circ} \mathrm{C}$ are shown in Fig.6. The sensor also suggested good signal repeatability as shown in Fig.6. The response time, defined as the period up to the $90 \%$ of the response change is about $14-40 \mathrm{~s}$, and the recovery time is about $20-55 \mathrm{~s}$. For instance, the insetted figure in Fig. 6 indicates that the response time to $50 \times 10^{-6}$ acetone is about $14 \mathrm{~s}$, and the corresponding recovery time is about $24 \mathrm{~s} \mathrm{(1}$ point every $2 \mathrm{~s}$ ). As comparsion, Fig. 7 shows the responses of pure, $1 \%, 3 \%$, and $6 \% \mathrm{Y}$-doped $\mathrm{ZnO}$ nanofibers to acetone with different concentrations at $440{ }^{\circ} \mathrm{C} .1 \%$ Y-doped $\mathrm{ZnO}$ nanofibers based sensor exhibits the higher response. The sensor based on $1 \% \mathrm{Y}$-doped $\mathrm{ZnO}$ nanofibers exhibits a brilliant selectivity to acetone at operating temperature $440^{\circ} \mathrm{C}$ as shown in Fig. 8 . We can see that the sensor response to $20 \times 10^{-6}$ acetone is about 4 times higher than those to ammonia $\left(\mathrm{NH}_{3}\right)$, benzene $\left(\mathrm{C}_{6} \mathrm{H}_{6}\right)$, formaldehyde $(\mathrm{HCHO})$, toluene $\left(\mathrm{C}_{6} \mathrm{H}_{5} \mathrm{CH}_{3}\right)$, and methanol $\left(\mathrm{CH}_{3} \mathrm{OH}\right)$, respectively. The possible reason for good selectivity to acetone is that the acetone has a single aldehyde and high reducibility in detecting gases. Simultaneously, acetone can be adsorbed on the surface of $\mathrm{ZnO}$ nanofibers more easily

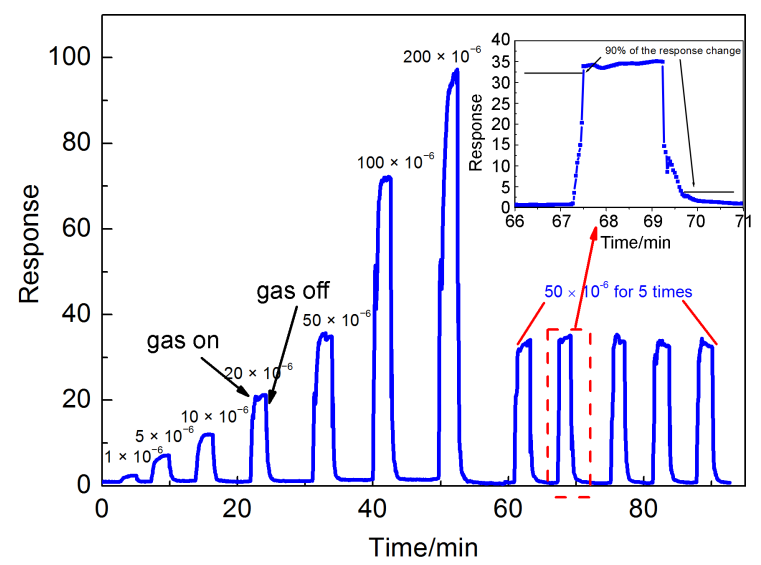

Fig.6 Responses and reversibility of $1 \%$ Y-doped $\mathrm{ZnO}$ nanofibers based sensor to acetone of $(1-200) \times 10^{-6}$

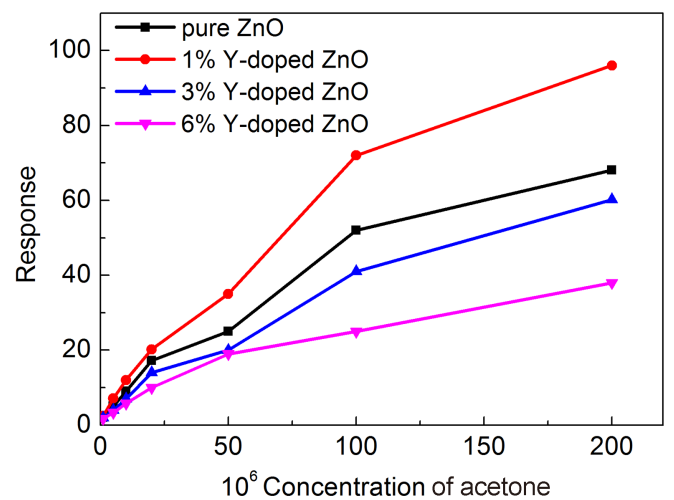

Fig.7 Responses of pure and Y-doped $\mathrm{ZnO}$ nanofibers based sensor to acetone of different concentrations than other reductive gases because of its relative higher boiling point and the adsorbed oxygen tends to oxidize the acetone into $\mathrm{H}_{2} \mathrm{O}$ and $\mathrm{CO}_{2}$.

\subsection{Gas sensing mechanism}

As a typical $n$-type semiconductor sensor, the sensitivity of the $\mathrm{Y}$-doped $\mathrm{ZnO}$ nanofibers based sensor is attributed to the chemisorptions of oxygen on the oxide surface and the subsequent reaction between adsorbed oxygen and targeted gas, leading to the change in the resistance of the sensor. The Debye length $\left(L_{\mathrm{d}}\right)$ of $\mathrm{ZnO}$ is changed by doping $\mathrm{Y}$, confirming by $1 \%$ $\mathrm{Y}$-doped $\mathrm{ZnO}$ nanofibers based sensor exhibiting the higher response than pure $\mathrm{ZnO}$ nanofibers based sensor. ${ }^{6,33,34}$

In air ambient, Y-doped $\mathrm{ZnO}$ nanofibers based sensor adsorbs the oxygen molecule on the surface. The adsorbed oxygen is changed to various chemical absorptive status $\left(\mathrm{O}_{2}^{-}, \mathrm{O}^{2-}\right.$, and $\mathrm{O}^{-}$) by capturing electrons from the conductance band (Equations (1)-(4)):

$$
\begin{aligned}
& \mathrm{O}_{2(\mathrm{~g})} \rightleftharpoons \mathrm{O}_{2(\mathrm{ads})} \\
& \mathrm{O}_{2(\mathrm{ads})}+\mathrm{e}^{-} \rightarrow \mathrm{O}_{2(\mathrm{ads})}^{-} \\
& \mathrm{O}_{2(\mathrm{ads})}^{-}+\mathrm{e}^{-} \rightarrow 2 \mathrm{O}_{(\mathrm{ads})}^{-} \\
& \mathrm{O}_{(\mathrm{ads})}^{-}+\mathrm{e}^{-} \rightarrow \mathrm{O}_{(\mathrm{ads})}^{2-}
\end{aligned}
$$

Consequently, the sensor presents a high-resistance status. The stable adsorbed oxygen ions are $\mathrm{O}_{2}^{-}$below $100{ }^{\circ} \mathrm{C}, \mathrm{O}^{-}$ between 100 and $300{ }^{\circ} \mathrm{C}$, and $\mathrm{O}^{2-}$ above $300{ }^{\circ} \mathrm{C}$ in $\mathrm{Y}$-doped $\mathrm{ZnO}$ nanofibers, respectively. ${ }^{35}$ When the operating temperature is $440{ }^{\circ} \mathrm{C}$, the $\mathrm{O}^{2-}$ is believed to be the dominant type. Normally, when the sensor is exposed to reductive gas, the reductive gas $(\mathrm{R})$ may interact with the oxide ions $\mathrm{O}^{2-}$ (Equation (5)):

$$
\mathrm{R}+\mathrm{O}_{\text {ads }}^{2-} \rightarrow \mathrm{RO}+2 \mathrm{e}^{-}
$$

which means that the produced electrons go back to the conduction band of the material and its conductivity increases. For instance, when $\mathrm{Y}$-doped $\mathrm{ZnO}$ nanofibers based sensor is exposed to reductive gas acetone $\left(\mathrm{CH}_{3} \mathrm{COCH}_{3}\right)$, the $\mathrm{CH}_{3} \mathrm{COCH}_{3}$ molecules will react with adsorbed $\mathrm{O}^{2-}$ species to form $\mathrm{CO}_{2}$ and $\mathrm{H}_{2} \mathrm{O}$, meanwhile, leading to an increase of carrier concentration

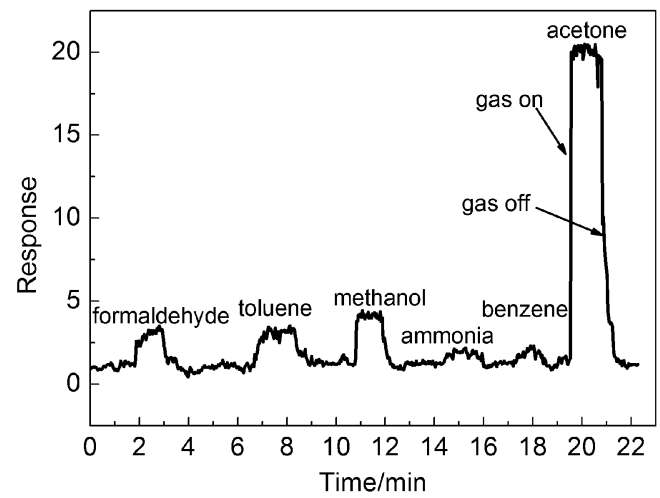

Fig.8 Selectivity of the response of the $1 \%$ Y-doped $\mathrm{ZnO}$ nanofibers based sensor to $20 \times 10^{-6}$ of methanol, formaldehyde, acetone, ammonia, benzene, and toluene 
(a)
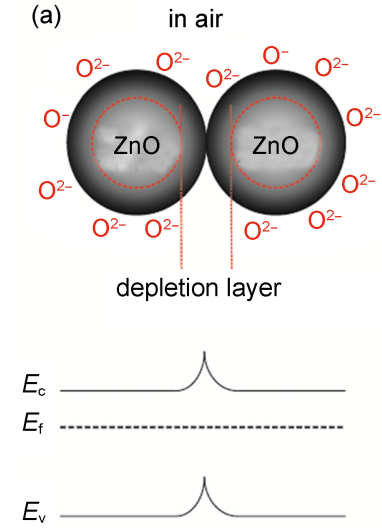

exposed to acetone

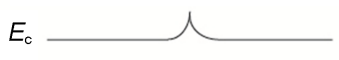

$E_{\mathrm{f}}$

$E_{\mathrm{v}}$

Fig.9 Schematic illustration of the sensing processes of (a) pure $\mathrm{ZnO}$ and (b) Y-doped $\mathrm{ZnO}$ nanofibers based sensors to acetone

$E_{\mathrm{c}}$ and $E_{\mathrm{v}}$ refer to the energies at the bottom of conduction band and at the top of valence band, respectively. $E_{\mathrm{f}}$ is the Fermi energy.

and a decrease of electrical resistance of the sensing material (Equation (6))

$$
\mathrm{CH}_{3} \mathrm{COCH}_{3(\mathrm{~g})}+\mathrm{O}_{\mathrm{ads}}^{2-} \rightarrow \mathrm{CO}_{2(\mathrm{~g})}+\mathrm{H}_{2} \mathrm{O}_{(\mathrm{g})}+2 \mathrm{e}^{-}
$$

Based on the above, the sensing process could be illustrated in Fig.9. As a catalyst, Y will support the catalytic conversion of acetone to its oxidation products, which is called chemical sensitization. This effect can accelerate the sensing reaction on the surface effectively. ${ }^{36,37}$ And also the increased oxygen vancancies and other defects introduced by Y doping will offer more active sites for the reactions. When Y-doped $\mathrm{ZnO}$ nanorods are exposed to acetone vapor, the barrier height of the material will become lower and depletion layer will be thinner, resulting in bigger change of the resistance of the sensitive material. Therefore, the response of the Y-doped $\mathrm{ZnO}$ nanofibers to acetone vapor increases. The resistance of the $1 \% \mathrm{Y}$-doped $\mathrm{ZnO}$ sensor $\left(R_{\mathrm{g}}\right)$ is smaller than that of pure $\mathrm{ZnO}$ when exposed to acetone vapor. In this experiment, we also found the samples with the excess $\mathrm{Y}$ concentration such as $3 \%$ and $6 \%$, the resistances $\left(R_{\mathrm{a}}\right)$ of which were very large, but the changes of the resistances were not so large when exposed to acetone vapor, which may be related to the increase of the defect concentration in crystal lattice and needs to be further studied.

\section{Conclusions}

In this article, pure and Y-doped $\mathrm{ZnO}$ nanofibers were successfully synthesized by the state of art electrospinning technique. Gas sensing investigation reveals that Y-doping can enhance the sensing properties of $\mathrm{ZnO}$ nanofibers efficiently to acetone with concentration ranging from $1 \times 10^{-6}$ to $200 \times 10^{-6}$ (volume fraction), and the optimal doping concentration of $\mathrm{Y}$ was $1 \%$ (atomic fraction). The sensor got good selectivity of acetone to ammonia, benzene, formaldehyde, toluene, and methanol. The enhanced sensing performances were mainly attributed to doping yttrium element as a catalyst to support the catalytic conversion of acetone to its oxidation products, and the introduction of oxygen vancancies and other defects as the active sites for the reactions by doping Y element.

\section{References}

(1) Huang, M. H.; Mao, S.; Feick, H.; Yan, H.; Wu, Y.; Kind, H.; Weber, E.; Russo, R.; Yang, P. Science 2001, 292, 1897. doi: 10.1126/science. 1060367

(2) Choi, S. H.; Ankonina, G.; Youn, D. Y.; Oh, S. G.; Hong, J. M.; Rothschild, A.; Kim, I. D. ACS Nano 2009, 3, 2623. doi:10.1021/nn900126k

(3) Zhang, Y.; Xu, J.; Xiang, Q.; Li, H.; Pan, Q.; Xu, P. J. Phys. Chem. C 2009, 113, 3430. doi:10.1021/jp8092258

(4) Bal, A. K.; Singh, A.; Bedi, R. K. Appl. Phys. A: Mater. Sci. Process. 2010, 103, 497. doi: 10.1007/s00339-010-6021-5

(5) Youn, S. K.; Ramgir, N.; Wang, C.; Subannajui, K.; Cimalla, V.; Zacharias, M. J. Phys. Chem. C 2010, 114, 10092. doi: 10.1021/jp100446r

(6) Yamazoe, N. Sens. Actuators B 1991, 5, 7. doi:10.1016/09254005(91)80213-4

(7) Tang, W.; Wang, J.; Yao, P. J.; Du, H. Y.; Sun, Y. H. Acta Phys. -Chim. Sin. 2014, 30, 781. [唐 伟, 王 咕, 姚朋军, 杜海 英, 孙炎辉. 物理化学学报, 2014, 30, 781.] doi: 10.3866/PKU.WHXB201402191

(8) Du, H. Y.; Wang, J.; Qiao, Q.; Sun, Y. H.; Shao, Q.; Li, X. G. Acta Phys. -Chim. Sin. 2015, 31, 800. [杜海英, 王 兢, 乔 俏, 孙炎辉, 邵 强, 李晓干. 物理化学学报, 2015, 31, 800.] doi: 10.3866/PKU.WHXB201501283

(9) Niu, X.; Du, W.; Du, W. Sens. Actuators B 2004, 99, 405. doi: 10.1016/j.snb.2003.12.007

(10) Sahay, P. P.; Nath, R. K. Sens. Actuators B 2008, 133, 222. doi: 10.1016/j.snb.2008.02.014

(11) Wei, S.; Yu, Y.; Zhou, M. Mater. Lett. 2010, 64, 2284. doi: 10.1016/j.matlet.2010.07.038

(12) Jia, T.; Wang, W.; Long, F.; Fu, Z.; Wang, H.; Zhang, Q. Mater. Sci. Eng. B 2009, 162, 179. doi: 10.1016/j.mseb.2009.04.004

(13) Kaur, R.; Singh, A. V.; Sehrawat, K.; Mehra, N. C.; Mehra, R. M. J. Non-Cryst. Solids 2006, 352, 2565. doi: 10.1016/j.jnoncrysol.2006.01.090

(14) Son, D. H.; Kim, D. H.; Kim, J. H.; Park, S. N.; Sung, S. J.; Kang, J. K. J. Nanosci. Nanotechnol. 2013, 13, 4211. doi: 10.1166/jnn.2013.7026

(15) Kılınç, N.; Öztürk, S.; Arda, L.; Altındal, A.; Öztürk, Z. Z. J. Alloy. Compd. 2012, 536, 138. doi: 10.1016/j.jallcom.2012.04.104

(16) Greiner, A.; Wendorff, J. H. Angew. Chem. 2007, 46, 5670. doi: 10.1002/anie. 200604646 
(17) Zheng, Y.; Wang, J.; Yao, P. Sens. Actuators B 2011, 156, 723. doi: 10.1016/j.snb.2011.02.026

(18) Wang, J.; Zou, B.; Ruan, S.; Zhao, J.; Chen, Q.; Wu, F. Mater. Lett. 2009, 63, 1750. doi: 10.1016/j.matlet.2009.05.046

(19) Cheng, L.; Ma, S. Y.; Li, X. B.; Luo, J.; Li, W. Q.; Li, F. M.; Mao, Y. Z.; Wang, T. T.; Li, Y. F. Sens. Actuators B 2014, 200, 181. doi: 10.1016/j.snb.2014.04.063

(20) Liang, Y. X.; Chen, Y. J.; Wang, T. H. Appl. Phys. Lett. 2004, 85, 666. doi: 10.1063/1.1775879

(21) Yao, P. J.; Wang, J.; Chu, W. L.; Hao, Y. W. J. Mater. Sci. 2012, 48, 441. doi: 10.1007/s10853-012-6758-7

(22) Abdelrazek, E. M.; Elashmawi, I. S.; Labeeb, S. Phys. B (Amsterdam, Neth.) 2010, 405, 2021. doi: 10.1016/j.physb.2010.01.095

(23) Zheng, J. H.; Song, J. L.; Jiang, Q.; Lian, J. S. Appl. Surf. Sci. 2012, 258, 6735. doi: 10.1016/j.apsusc.2012.03.010

(24) Heo, S.; Sharma, S. K.; Lee, S.; Lee, Y.; Kim, C.; Lee, B.; Lee, H.; Kim, D. Y. Thin Solid Films 2014, 558, 27. doi: 10.1016/j.tsf.2014.02.025

(25) Yogamalar, R.; Venkateswaran, P. S.; Benzigar, M. R.; Ariga, K.; Vinu, A.; Bose, A. C. J. Nanosci. Nanotechnol. 2012, $12,75$. doi: 10.1166/jnn.2012.5760

(26) Guo, W.; Liu, T.; Sun, R.; Chen, Y.; Zeng, W.; Wang, Z. Sens. Actuators B 2013, 178, 53. doi: 10.1016/j.snb.2012.12.073

(27) Zhang, C.; Chen, P.; Hu, W. Chem. Soc. Rev. 2015, 44, 2087. doi: $10.1039 / \mathrm{c} 4 \mathrm{cs} 00326 \mathrm{~h}$

(28) Yamazoe, N.; Fuchigami, J.; Kishikawa, M.; Seiyama, T. Surf. Sci. 1979, 86, 335. doi: 10.1016/0039-6028(79)90411-4

(29) Herrán, J.; Fernández-González, O.; Castro-Hurtado, I.; Romero, T.; GMandayo, G.; Castaño, E. Sens. Actuators B 2010, 149, 368. doi: 10.1016/j.snb.2010.06.050

(30) Ghasdi, M.; Alamdari, H. Sens. Actuators B 2010, 148, 478. doi: 10.1016/j.snb.2010.05.056

(31) Zhao, M.; Wang, X.; Ning, L.; Jia, J.; Li, X.; Cao, L. Sens. Actuators B 2011, 156, 588. doi: 10.1016/j.snb.2011.01.070

(32) Wang, P.; He, J.; Guo, L.; Yang, Y.; Zheng, S. Mater. Sci. Semicond. Process. 2015, 36, 36. doi: 10.1016/j.mssp.2015.03.022

(33) Wan, Q.; Li, Q. H.; Chen, Y. J.; Wang, T. H.; He, X. L.; Li, J. P.; Lin, C. L. Appl. Phys. Lett. 2004, 84, 3654. doi: $10.1063 / 1.1738932$

(34) Shimizu, Y.; Kai, S.; Takao, Y.; Hyodo, T.; Egashira, M. Sens. Actuators B 2000, 65, 349

(35) Takata, M.; Tsubone, D.; Yanagida, H. J. Am. Ceram. Soc. 1976, 59, 4. doi: 10.1111/j.1151-2916.1976.tb09374.x

(36) Franke, M. E.; Koplin, T. J.; Simon, U. Small 2006, 2, 36. doi: 10.1002/smll.200500261

(37) Liu, L.; Li, S.; Zhuang, J.; Wang, L.; Zhang, J.; Li, H.; Liu, Z.; Han, Y.; Jiang, X.; Zhang, P. Sens. Actuators B 2011, 155, 782. doi: 10.1016/j.snb.2011.01.047 